\title{
The Effect of the Degree of Gelation on the Capillary Flow Properties of PVC Melts
}

\author{
by \\ Mitsuyoshi Fujiyama and Satoshi Nagou \\ (Research and Development Center, Tokuyama Soda Co., Ltd., Tokuyama)
}

The change of the gelation state of PVG particles during mixing with a Brabender plastograph was observed by eye and with an electron microscope. At the same time mixtures with different degrees of gelation were prepared with reference to the torque curve, and the effect of the degree of gelation on the capillary flow properties was examined by means of a Koka flow tester.

At the peak position of the torque curve, gelation was incomplete and some particle structure still remained. At a position a little past the peak, a honogeneous structure was attained and gelation was complete.

With increasing gelation, the viscosity increased and also the Barus effect and melt fracture distortions, which are due to melt elasticity, became more noticeable. Moreover, these properties were more pronounced in a material prepared by a tin formulation than in one prepared by a lead formulation; the former is easier to gelate than the latter.

These experimental results support Berens's hypothesis namely, that an increase of gelation couses the particle flow mechanism to shift to a homogeneous flow mechanism, with a resulting increase ih the viscosity and elasticity.

However, the end correction coefficient, which is another measure of elasticity in capillary flow, decreased with an increase of gelation and was larger in the lead formulation that in the tin formulation. Consequently, it may be assumed that the end correction coefficient is an inadequate measure of elasticity, at least in materials such as PVC compounds which have inhomogeneous structure and exhibit dilatant flow behavior.

\section{PVC の流動性に及ぼすゲル化度の影響}

\author{
藤 山 光 美* 名 郷 訓 也*
}

（原稿受理：1973年12月27日）

\section{1. 緒}

\section{言}

PVC は, その微結晶融点が $200^{\circ} \mathrm{C}$ 以上であるため ${ }^{1)}$, 通常の成 形温度においても粒子構造が堅固で, ゲル化度が流動性に影響を 及ぼすてとが実際の成形の際観察されている. 例えば押出成形に おいてゲル化が不充分の場合は融着不足で, きれいな押出物が得 られないが，逆にゲル化が進み過ぎても押出トルクの上昇や肌荒 れの発生がみられる2).

Berens $ら^{3)}$ は種々の温度で圧縮成形した乳化重合 PVG の毛管 流動特性を測定し，プレス温度が高くなり均一構造に近づくにつ れて, 粘性, 弾性 (Barus 効果) とも增大するととを見出し,

* 德山曹達株式会社技術研究所 徳山市御影町一番一号
“粒子流動”という概念を提出した. すなわち, 通常の高分子溶 融物では, 流動単位は分子鎖セグメントでありその移動により流 動を生じているが，低温で圧縮成形した乳化重合 PVCでは粒子 が流動単位となり，それらが互に相対的位置をかえながら流動し ているというものである.

本研究においては, 懸濁重合 PVGにつき, ブラベンダー・プ ラストグラフを用い, そのトルクー時間曲線を参考にして, 混練 温度一定で混練時間を変えることによって種々のゲル化度の試料 を作り, その毛管流動特性に及ぼず゙ル化度の影響を実験的に検 討した. なおゲル化状態は肉眼的観察およびその微細組織を電子 顕微鏡により観察し，プラストグラフにおけるゲル化の過程を追 跡した．また押出物の引張試験からもゲル化状態を推定しだ 


\section{2. 実}

\section{験}

PVG は，懸濁重合 PVC であるサンアロー化学製 Ryuron-S, 800B $(\bar{P}=800)$ を用いた，硬質 PVC の配合には大別して Sn 系 配合と $\mathrm{Pb}$ 系配合とがあるが，本研究においては複雑な配合は さけ，なるべく基本的なものとして以下に示す二種の配合を用い た.

$\mathrm{Sn}$ 配合 $\left\{\begin{array}{lr}\mathrm{PVG} \text { 樹脂 } & 100 \text { 部 } \\ \text { ジブチル錫マレェート系安定剤 } & 3 \text { 部 } \\ \text { ステアリン酸ブチル } & 1 \text { 部 }\end{array}\right.$
$\mathrm{Pb}$ 配合 $\left\{\begin{array}{lr}\mathrm{PVG} \text { 樹脂 } & 100 \text { 部 } \\ \text { 三塩基性硫酸鉛 } & 3 \text { 部 } \\ \text { ステアリリン酸 } & 1 \text { 部 }\end{array}\right.$

上記コンパウンドを乳鉢で十分混合し，ブラベンダー・プラス トグラフにより混練を行なった，混練条件は，ジャケット温度； $155^{\circ} \mathrm{C}$ ，ローター回転数； $30 \mathrm{rpm}(\mathrm{Pb}$ 配合では $30 \mathrm{rpm}$ ではゲル 化しなかったので $60 \mathrm{rpm}$ とした), 陚料仕込量；60 g である.

Fig. 1 はプラストグラフによるトルクおよび樹脂温度の潉練に よる時間的変化曲線を示す．図中矢印で示した各点において試料 を採取した。電顕によるゲル化状態の観察は，プラストグラフか ら分取した武料約 $3 \mathrm{~g}$ を高化式フローテスターのシリンダーの中 そ装填し, $160^{\circ} \mathrm{C} て ゙ 60 \mathrm{~kg} / \mathrm{cm}^{2}$ の荷重をかけて 10 分間压縮成形して 得た丸棒状の試片を液体窒素温度条件下で引張りながら曲げ破断 し，破断面のレプリ写真をとった。流動特性は, 高化式フロー テスターを用いて測定した。 使用したダイは, 半径 $R=0.25 \mathrm{~mm}$ 長さ $L=1,2,25,3.5,5 \mathrm{~mm}(L / R=4,8,10,14,20)$ の 5 種

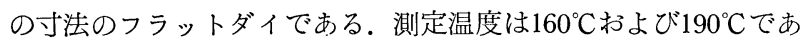
る. $190^{\circ} \mathrm{C}$ で測定した試料については，みかけのせん断応力 $\tau_{W}{ }^{\prime}$ を Bagley の方法 ${ }^{4}$ により有効せん断応力 $\tau$ に またみかけのせ ん断速度 $\dot{r}_{W^{\prime}}$ を Rabinowitsch の式 ${ }^{5)}$ にり真のせん断速度 $\dot{\gamma}$

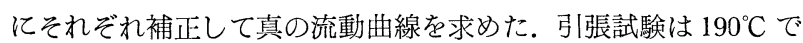
押出した試料について, 初期長 $3.0 \mathrm{~cm}$, 引張速度 $20 \mathrm{~mm} / \mathrm{min}$ の 条件で, 室温 $\left(23^{\circ} \mathrm{C}\right)$ において行なった。

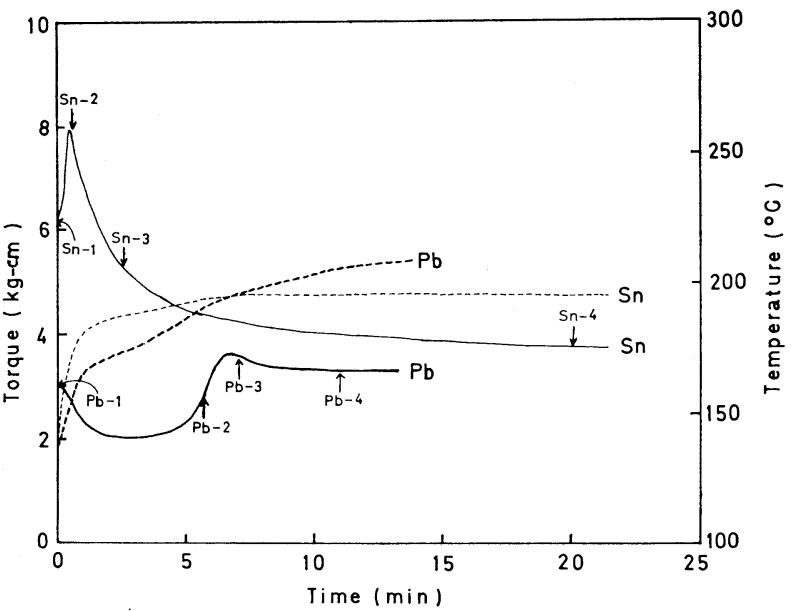

Fig. 1. Torque and temperature curves from the Brabender plastograph. The solid line and the broken line are the torque and the temperature, respectively. The samples for the flow test were selected at the positions marked by arrows.

\section{3. 実験結果および考察}

\section{$3 \cdot 1$ 混練物の肉眼による観察}

各混練物の性状をFig. 2 亿示す. Sn 配合についてみると, Sn-1 は乳鉢で混合しただけであり混練以前の粉末状である。プラスト グラフのトルク曲線のピーク位置で採取した Sn-2 は部分的に融 着した程度でまだ粉末性が大きくゲル化はわずかである．Sn-4 になると完全にゲル化して融着し，Sn-3 は Sn-2 と Sn-4 の中間 的な性状を示す。つぎに $\mathrm{Pb}$ 配合については Pb-1 は乳鉢で混合 した混練以前のものである．トルク曲線の立上り部分の中間位置 で採取した $\mathrm{Pb}-2$ はわずかけゲル化してかたまりにはなっている が手でもむと粉末となる。トルク曲線のピーク位置で採取した $\mathrm{Pb}-3$ ではほぼ融着してはいるが，粉末性がまだわずかに存在す る. そして Pb-4 になると完全にゲル化が完了して融着したもの となる．以上の結果から $\mathrm{Pb}$ 配合の場合ではトルク曲線がピーク を示す時間をゲル化時間とするのは適当であるが，しかしてれに 対して，ピーク時間の非常に短いSn 配合においては, トルク曲 線がピークを示す時間をら゙ル化時間とするのは，本実験結果から は不適当のように思气る。

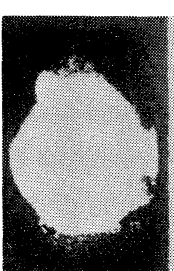

Sn-1

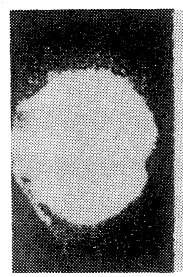

$\mathrm{Pb}-1$

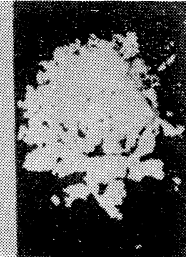

$\mathrm{Sn}-2$

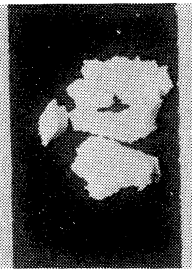

$\mathrm{Pb}-2$

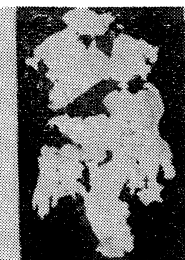

Sn-3

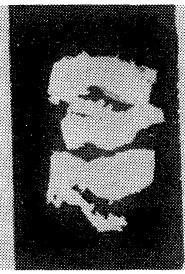

$\mathrm{Pb}-3$

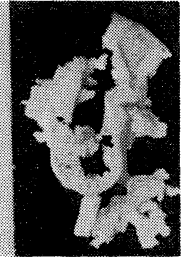

Sn-4

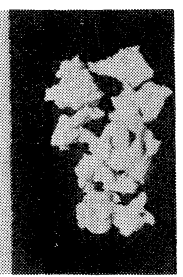

$\mathrm{Pb}-4$
Fig. 2. Mixtures selected at the marked positions in Fig. 1.

\section{$3 \cdot 2$ 電子顕微鏡によるゲル化状態の観察}

Fig. 3 亿各混練物の破断面レプリカ電顕写真を示す. Pb-1 試 料はよく固まらなかったのでレプリカがとれず，写真が得られな かった. $\mathrm{Sn}$ 配合, $\mathrm{Pb}$ 配合ともトルク曲線のピーク位置で採取し た混練物（Sn-2, Pb-3）においてもまだ不均一な構造をしており ゲル化は不充分である。ピークをかなり過ぎた試料 ( $\mathrm{Sn}-3, \mathrm{~Pb}-4)$ ではじめて均一構造をとっておりゲル化が完了したてとを示す。 すなわちトルク曲線のピークを少し過ぎた点においてゲル化が完 了する。乙のととからトルク曲線のピーク位置をゲル化時間とす るのは便宜的には意味があろうが铰密には適切でないと言えよう。 これに対してトルク曲線か泙衡值に達するゲル化終了時間におい てはゲル化は完了している。乙のことは肉眼による混練物の観察 結果とも一致する。

なお，落合 ${ }^{6}$ とよればトルク曲線のピーク位置の樹脂温度は配 合，混練条件によらずほぼ一定值を示し，ゲル化の因子は温度だ 


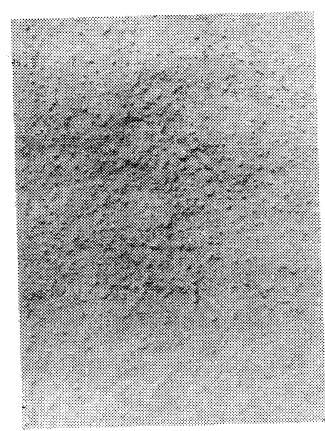

Sn -1

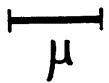

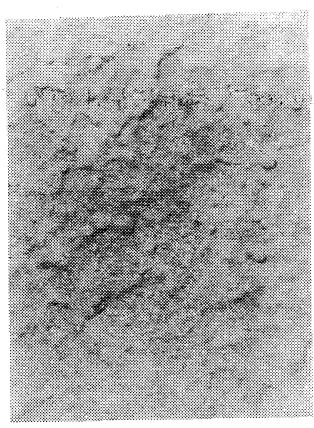

$\mathrm{Sn}-2$

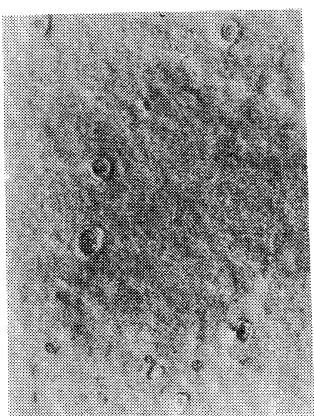

$\mathrm{Pb}-2$

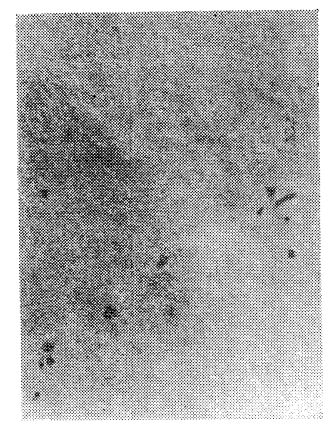

Sn -3

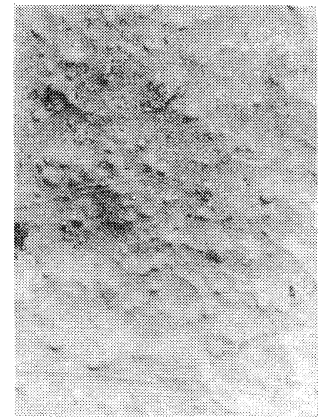

$\mathrm{Pb}-3$

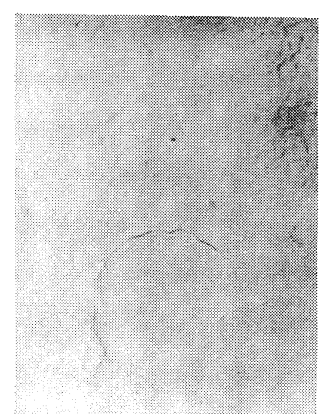

$5 n-4$

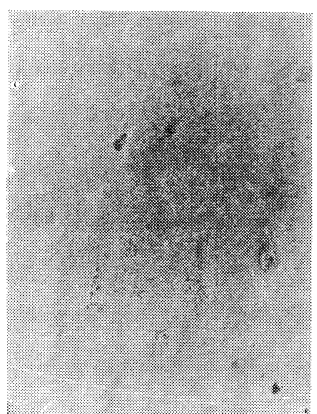

$\mathrm{Pb}-4$

Fig. 3. Electron micrographs of the fracture surface replica, for the mixtures in Fig. 2.

Table I. Tensile test of the extrudate

\begin{tabular}{cccc}
\hline Samples & $\begin{array}{c}\text { Yield Stress } \\
\left(\mathrm{kg} / \mathrm{cm}^{2}\right)\end{array}$ & $\begin{array}{c}\text { Elongation } \\
(\%)\end{array}$ & $\begin{array}{c}\text { Young's Modulus } \\
\left(10^{4} \mathrm{~kg} / \mathrm{cm}^{2}\right)\end{array}$ \\
\hline $\mathrm{Sn}-1$ & 505 & 78 & 1.82 \\
$\mathrm{Sn}-2$ & 499 & 175 & 1.92 \\
$\mathrm{Sn}-3$ & 525 & 170 & 2.12 \\
$\mathrm{Sn}-4$ & 547 & 111 & 2.20 \\
\hline $\mathrm{Pb}-1$ & 407 & 16 & 1.63 \\
$\mathrm{~Pb}-2$ & 494 & 183 & 1.90 \\
$\mathrm{~Pb}-3$ & 498 & 176 & 1.98 \\
$\mathrm{~Pb}-4$ & 513 & 207 & 1.87 \\
\hline
\end{tabular}

けであるとしているが，本実験では $\mathrm{Sn}$ 配合と $\mathrm{Pb}$ 配合とではそ れぞれ $175^{\circ} \mathrm{C}$ と $193^{\circ} \mathrm{C}$ で約 $20^{\circ} \mathrm{C}$ 差を示すととから落合の結果と一 致していない.

Table I 亿各混練物試料の押出物の引張試験結果を示す. 降伏 強度, 破断伸度, ヤング率とも混練時間が長いものほど大きい值 を示している.未混練物である Sn-1 (降伏強度を除いて) および $\mathrm{Pb}-1$ は特に小さい值を示す。てれらの実験結果は混練度が進む につれて均一構造となっていることを意味する。

\section{$3 \cdot 4$ 毛管流動特性}

$L / R=20$ のダイを用いて得られたみかけの流動曲線をFig. 4 ，

Fig. 5 亿示す. Sn 配合の場合, ゲル化度は流動性にほとんど影 響を及ぼさない. $\mathrm{Pb}$ 配合については $160^{\circ} \mathrm{C} の$ 場合, $\dot{\gamma}_{W}{ }^{\prime}<10^{2} \mathrm{sec}^{-1}$ ではゲル化度の影響を受けないが. $\dot{\gamma}_{W}{ }^{\prime}>10^{2} \mathrm{sec}^{-1}$ ではゲル化の 進行とともに流動性は漸次低下する。 $190^{\circ} \mathrm{C}$ の場合, 低せん断側 で流動曲線の勾配が急になりダイラタントな流動》を示す。また

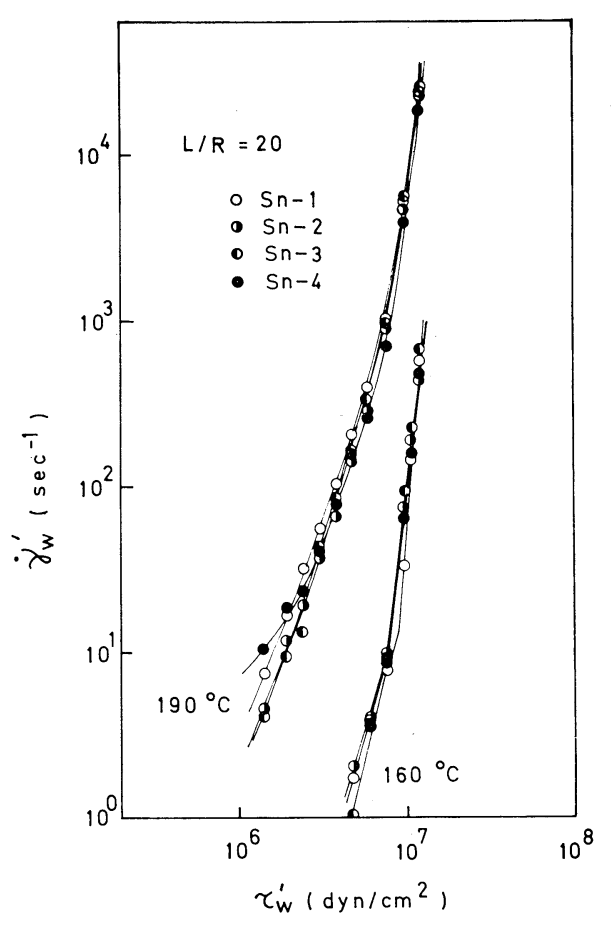

Fig. 4. Apparent flow curves for the Sn formulation.

そのため $\dot{\gamma}_{W}{ }^{\prime}<10^{2} \mathrm{sec}^{-1}$ そおけるデータの再現性が良くない. 再 現性の良い $\dot{r}_{w^{\prime}}>10^{2} \mathrm{sec}^{-1}$ の部分をみると, ゲル化の進行ととも 飞流動性は漸次低下し, Berens ら $^{33}$ の結果と同様な傾向を示す。 $\mathrm{Sn}$ 配合と $\mathrm{Pb}$ 配合とでは $\mathrm{Pb}$ 配合の方が流動性が良く, $\mathrm{Pb}-4$ と Sn 配合の流動曲線はほぼ一致する。 


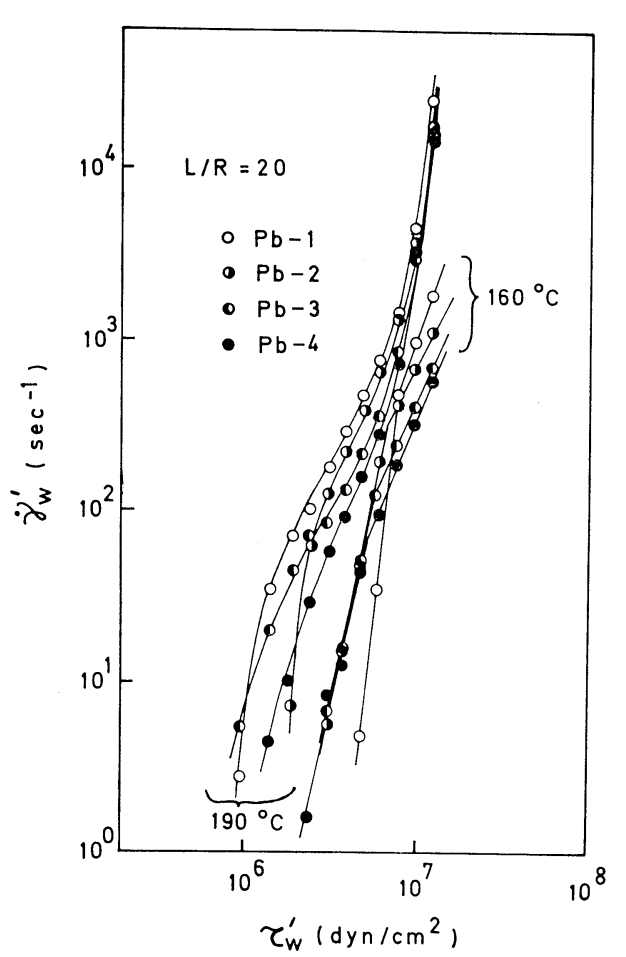

Fig. 5. Apparent flow curves for the $\mathrm{Pb}$ formulation.

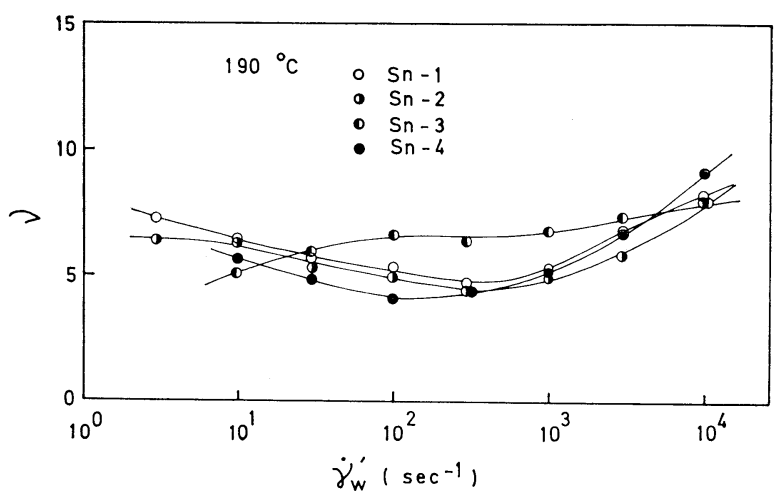

Fig. 6. End correction coefficient $\nu$ vs. apparent shear rate $\dot{\gamma}_{W}{ }^{\prime}$ for the Sn formulation.

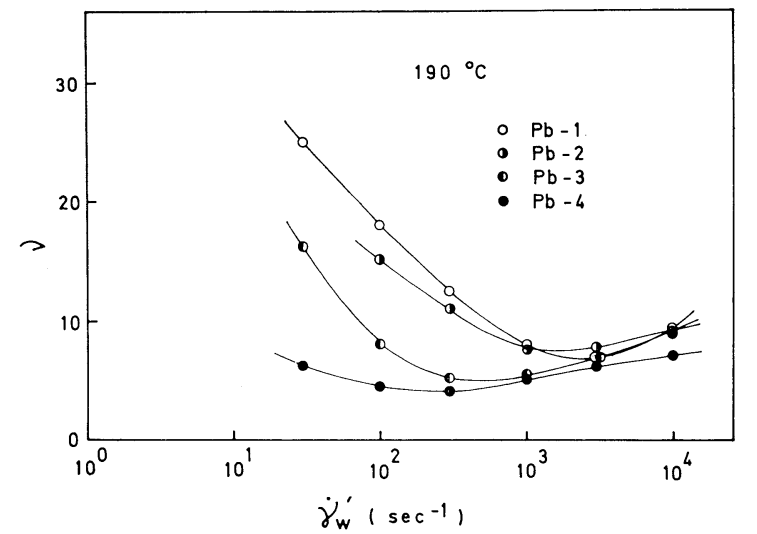

Fig. 7. End correction coefficient $\nu$ vs. apparent shear rate $\dot{\gamma}_{W}$ for the $\mathrm{Pb}$ formulation.

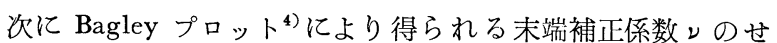
ん断速度変化をFig. 6 , Fig. 7 亿示す. Sn 配合では $\dot{\gamma}_{W}{ }^{\prime} 3 \times$ $10^{2} \mathrm{sec}^{-1}$ 付近に最小值を有する曲線となり，ゲル化度の影響は Sn-3 を除いて流動曲線の場合と同様ほとんどない.一方 $\mathrm{Pb}$ 配 合ではせん断速度の減少につれて が増大し異常な挙動を示す

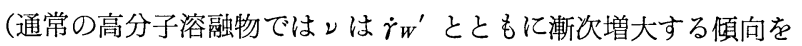
示す ${ }^{8)}$ ). これはFig. 8 の流動曲線からわかるように, 低せん断速 度にわいてダイラタントな傾向が強くなるととに起因しているも

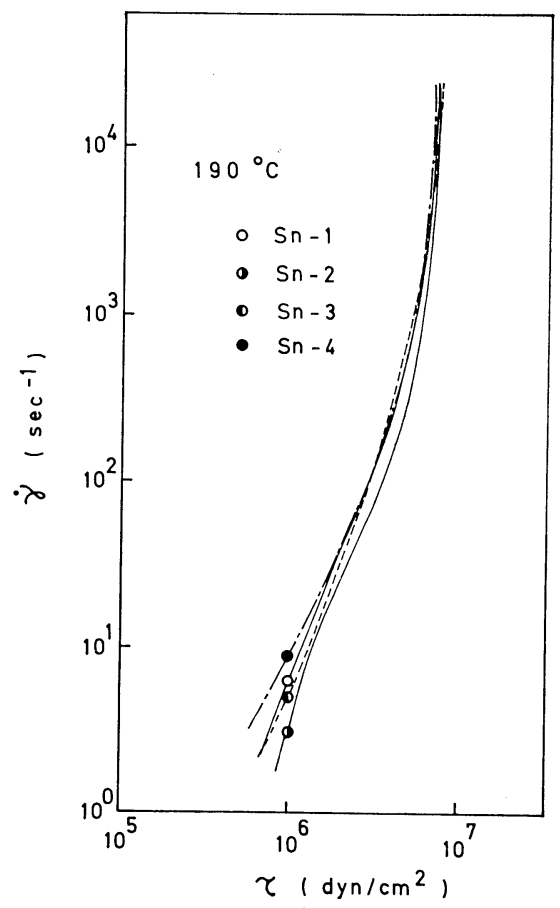

Fig. 8. True flow curves for the Sn formulation.

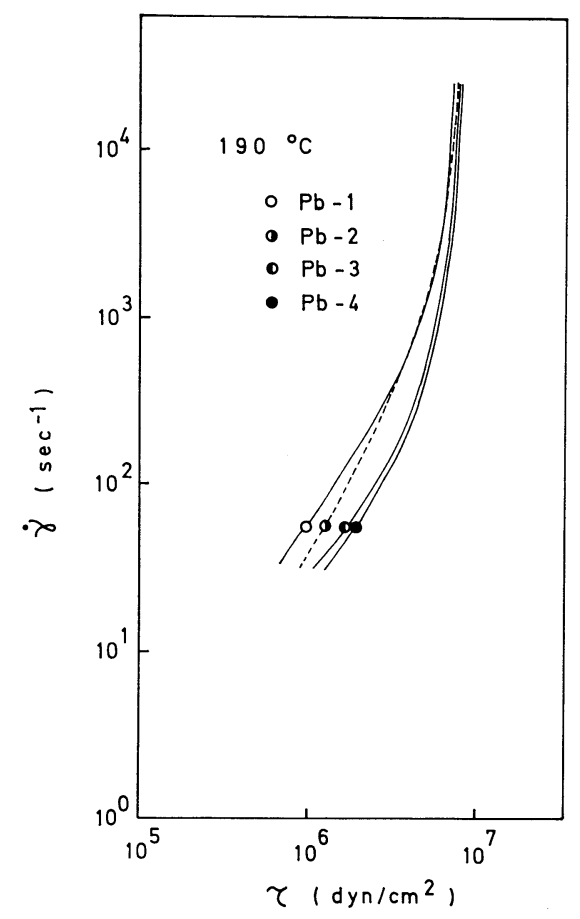

Fig. 9. True flow curves for the $\mathrm{Pb}$ formulation. 
のと考えられる.ゲル化度の影響は，ゲル化が進行するにつれて レは小さくなり, 弾性が弱くなるととを意味しており, Berens $ら^{3)}$ の仮説と一致しない。なお $\mathrm{Pb}$ 配合の場合には $\dot{r}_{W}{ }^{\prime}<3 \times 10^{1}$ $\sec ^{-1}$ において Bagley プロットのばらつきが大きくレを決定す るととが困難であった. $\mathrm{Sn}$ 配合と $\mathrm{Pb}$ 配合とを比較すると, $\mathrm{Pb}$ 配合の方がンの值が大きく, Pb-4 と Sn 配合混練物とがほぼ同 程度, 同傾向の $\nu の \dot{\gamma}_{W}{ }^{\prime}$ 変化を示す. 流入圧損失 $P_{0}$ について もSn 配合の場合にはゲル化度にほとんぞ依存せず， $\mathrm{Pb}$ 配合に おいてはゲル化の進行とともに $P_{0}$ は減小する.

真の流動曲線を Fig. 8, Fig. 9 亿示す. Sn 配合の場合ゲル化 度の影響をほとんど受けないが，Pb 配合の場合ゲル化の進行と ともに流動性が低下する。

Fig. 10, Fig. 11亿 Barus 効果 $D / D_{0}$ ( $D$ : 押出物の直径, $D_{0}$ : ダイ孔径）のせん断速度による変化を示す． $D / D_{0}$ は $\mathrm{Sn}$ 配合で は $\dot{\gamma}_{W}{ }^{\prime} \fallingdotseq 3 \times 10^{2} \mathrm{sec}^{-1}$ 付近に，そして $\mathrm{Pb}$ 配合では $\dot{\gamma}_{W} \fallingdotseq 10^{2} \mathrm{sec}^{-1}$ 付近にピークを有する上に凸な曲線となる。乳化重合 PVGにつ

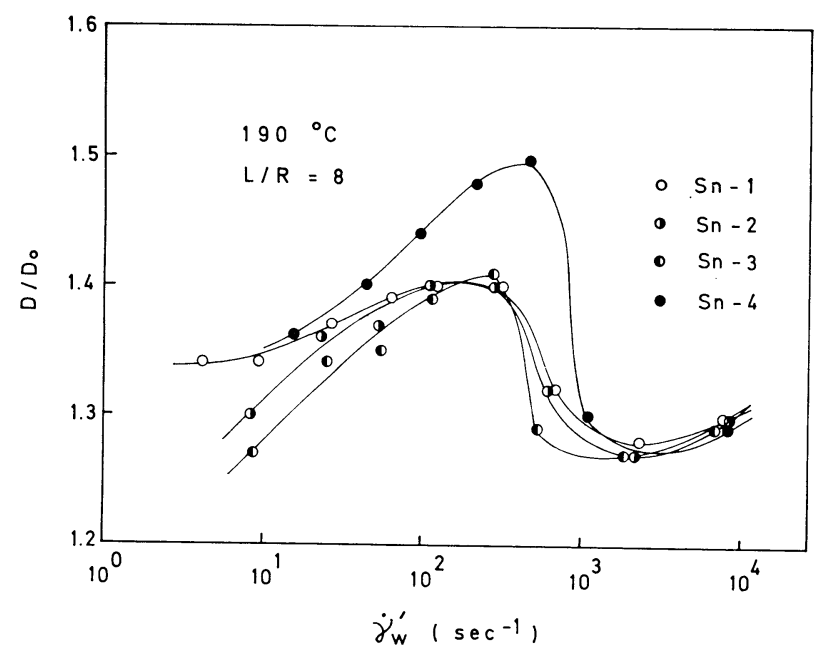

Fig. 10. Swelling ratio $D / D_{0} v s$. apparent shear rate $\dot{\gamma}_{W^{\prime}}$ for the Sn formulation. $D$ and $D_{0}$ are the diameters of the extrudate and capilary, respectively.

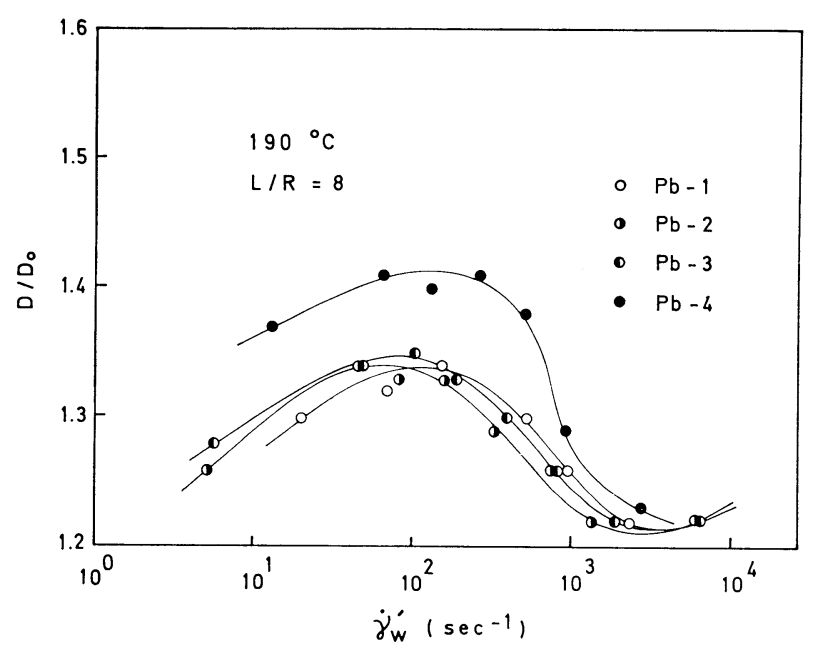

Fig. 11. Swelling ratio $D_{i}^{\prime} D_{0} v s$. apparent shear rate $\dot{\gamma}^{\prime}$ for the $\mathrm{Pb}$ formulation.
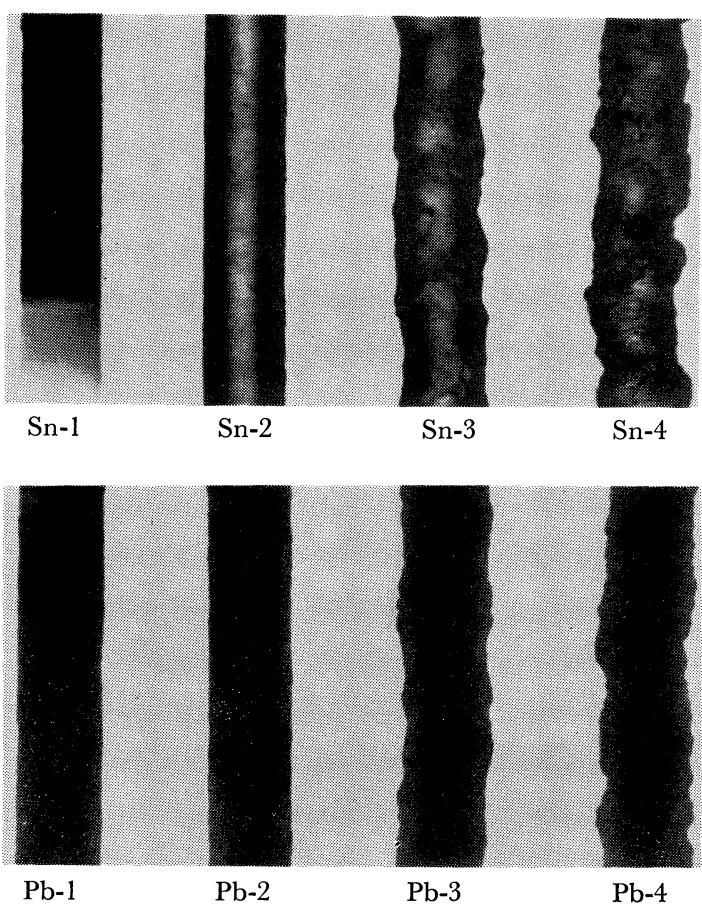

Fig. 12. Extrudates at the apparent shear stress $\tau_{W^{\prime}}=7.35$ $\times 10^{6} \mathrm{dyn} / \mathrm{cm}^{2}$.

いての Berens ら ${ }^{9)}$ の結果は本実験結果とは屰で, $\dot{r}_{W}{ }^{\prime}=10^{2} \mathrm{sec}^{-1}$ 付近に最小值を有する下に凸な曲線となっている．Sn 配合， $\mathrm{Pb}$ 配合ともBarus 効果は, 混練番号 3 まではゲル化度にほとんど 依存しないが，ゲル化の完全に進んだ 4 になると急に顕著になる。 $\mathrm{Sn}$ 配合と $\mathrm{Pb}$ 配合の $D / D_{0}$ の值を比較すると, $\mathrm{Sn}$ 配合の方が 大きく, $\mathrm{Pb}$ 配合においてゲル化の完全に進んだ $\mathrm{Pb}-4$ と $\mathrm{Sn}$ 配 合においてゲル化の不允分な Sn-1, 2, 3 とがほぼ同程度の值を 示す.

Fig. 12 亿 $160^{\circ} \mathrm{C}$ 押出物 $\left(L / R=20, \tau_{W}{ }^{\prime}=7.35 \times 10^{6} \mathrm{dyme} / \mathrm{cm}^{2}\right)$ の 写真を示す．ゲル化の進行とともにメルト・フラクチャーが激し くなっている. $\mathrm{Sn}$ 配合と $\mathrm{Pb}$ 配合とでは $\mathrm{Sn}$ 配合の方がメルト ・フラクチャーが激しい，乙の理由は，Sn 配合の方がゲル化し やすいため均一性が良く弾性的性質が強いてとによるものと考光 られる。

\section{4. 結論}

䯟濁重合 PVG のブラベンダー・プラストグラフによる混練に おいて, トルク曲線のピークを少し過ぎた点においてゲル化が完 了する。

毛管流動特性に及ぼすゲル化度の影響については，ゲル化が進 むにつれて粘度は增大し, 弾性に起因する Barus 効果およびメ ルト・フラクチャーは顕著になる。 またゲル化性の良好な Sn 配 合の方が $\mathrm{Pb}$ 配合よりてれらの諸性質はいずれも顕著である。し たがっててれらの実験事実から，ゲル化が進むにつれて粒子流動 から均一流動に移行し, その結果粘性, 弾性とも増大するという Berens $ら^{3)}$ の仮説を支持するととができる，ところが毛管流動に おける弾性の一尺度である末端補正係数はゲル化の進行とともに 減少し, またゲル化しにくい $\mathrm{Pb}$ 配合の方が $\mathrm{Sn}$ 配合より大きい.

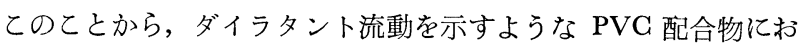


いて，末端補正係数を弾性の尺度とみなすのは不均一構造のもの ではあてはまらないものと考えることができる。

本研究の発表を許可された德山曹達株式会社技術研究所長尾上: 康治博士，第一部長泊康雄氏および有益な助言をいただいた粟屋 裕博士に深謝する。

（昭和48年10月24日，第21回レオロジー討論会で講演）

$$
\text { 5. 文献 }
$$

1) Pezzin, G., Pure and Applied Chemistry, 26, 〔2〕, 241 (1971).
2）藤山光美, 未発表データ

3) Berens, A.R., and V.L. Folt, Polym. Eng. Sci., 8 [1], 5 (1968).

4) Bagley, E.B., J. Appl. Phys., 28, 624 (1957).

5) Rabinowitsch, B., Z. Physik. Chem. (Leipzig) A145, 1 (1929).

6) 落合周一郎, 第21回高分子学会年次大会講演要旨集, p. 236 (1972).

7) Lenk, R.S., J. Appl. Phys., 28, 624 (1957).

8) Lyder, L.B., SPE Journal, Dec., 1305 (1961).

9) Berens, A.R., and V.L. Folt, Polym. Eng. Sci., 9 〔1], 29 (1969). 